\title{
TRAINING OF ARMY RESERVES IN THE EDUCATIONAL STRUCTURES OF MILITARY SETTLEMENTS IN THE FIRST HALF OF THE $19^{\text {th }}$ CENTURY
}

\author{
Tatiana N. Kandaurova \\ Russian State University for the Humanities, Moscow, Russian Federation
}

\begin{abstract}
Introduction. The article considers the development of military educational structures of the Russian military settlement organization at various stages of their activity. In the 1810s and 1850s, training battalions, squadrons, batteries, and combat reserve units trained children of Cantonese military settlers to serve in the army as Junior and non-commissioned officers. Specialized educational institutions taught topographers, builders, doctors, veterinarians, agronomists and other training specialists to serve in the settlement districts. Methods and materials. The author explores models of developing military educational institutions on the basis of materials of complexes of legislative, statistical and reporting documents applying methods of quantitative analysis (trend models, grouping method), comparative analysis using source-oriented, problem-oriented, and system-structural approaches. Analysis. All this made it possible to trace the evolution of government policy aimed at training army personnel and noncommissioned officers based on changing historical realities (the army's needs for trained personnel, the reform of the military settlement organization), and the results of its implementation, as well as to show the numerical corps of graduates of training units of military settlements and its growth in time and space. Results. The main stages of the development of military educational structures of settlements and periods of their quantitative growth are also defined, which resulted in the multiplication of the number of graduates for the army service. The formation and expansion of the entire educational system of settlements was carried out as the need for special-profile personnel arose in the settled regiments. In the $1820 \mathrm{~s}-1850 \mathrm{~s}$, new special educational institutions were integrated into it, and primary education developed along a transformed vector.
\end{abstract}

Key words: military settlements, Cantonese, Lancaster School, non-commissioned officer training, school squadrons, battalions and batteries, Military Teacher Training Institute.

Citation. Kandaurova T.N. Training of Army Reserves in the Educational Structures of Military Settlements in the First Half of the $19^{\text {th }}$ Century. Vestnik Volgogradskogo gosudarstvennogo universiteta. Seriya 4. Istoriya. Regionovedenie. Mezhdunarodnye otnosheniya [Science Journal of Volgograd State University. History. Area Studies. International Relations], 2021, vol. 26, no. 1, pp. 53-66. (in Russian). DOI: https://doi.org/10.15688/ jvolsu4.2021.1.6

УДК 94(47).073(093)

Дата поступления статьи: 01.07.2020

ББК 63.3(2)5

Дата принятия статьи: 03.09.2020

\section{ПОДГОТОВКА АРМЕЙСКИХ РЕЗЕРВОВ В УЧЕБНЫХ СТРУКТУРАХ ВОЕННЫХ ПОСЕЛЕНИЙ В ПЕРВОЙ ПОЛОВИНЕ ХІХ ВЕКА}

\author{
Татьяна Николаевна Кандаурова
}

Российский государственный гуманитарный университет, г. Москва, Российская Федерация

Аннотация. В статье рассматривается развитие военно-учебных структур российской военно-поселенной организации на различных этапах их деятельности. В 1810-1850-х гг. учебные батальоны, эскадроны, батареи и строевые резервные части осуществляли подготовку детей военных поселян - кантонистов к службе в армии в качестве младшего и унтер-офицерского состава. Профильные учебные заведения выпускали на службу в поселенные округа специалистов топографов, строителей, медиков, ветеринаров, агрономов и других направлений подготовки. Автор исследует модели развития военно-учебных заведений на основе материалов комплексов законодательных, статистических и отчетных документов с применением методов количественного анализа (трендовые модели, метод структурной группировки), компаративного анализа, 
используя источнико-ориентированный, проблемно-ориентированный, системно-структурный подходы. Все это позволило проследить эволюцию правительственной политики в вопросе подготовки армейских кадров и унтер-офицерского состава исходя из менявшихся исторических реалий (потребности армии в подготовленных кадрах, реформы военно-поселенной организации), и итоги ее реализации, а также показать численный корпус выпускников учебных подразделений военных поселений и его рост во временном и пространственном отношении. Определены основные этапы развития военно-учебных структур поселений и периоды их количественного роста, что вело и к умножению численности выпускников на армейскую службу. Формирование и расширение всей образовательной системы поселений осуществлялось по мере возникновения потребности поселенных полков в кадрах специального профиля. В 1820-1850-х гг. в нее были интегрированы новые специальные учебные заведения, начальное образование развивалось по изменявшемуся вектору.

Ключевые слова: военные поселения, кантонисты, ланкастерская школа, подготовка унтер-офицеров, учебные эскадроны, батальоны и батареи, Военно-учительский институт.

Цитирование. Кандаурова Т. Н. Подготовка армейских резервов в учебных структурах военных поселений в первой половине XIX века // Вестник Волгоградского государственного университета. Серия 4, История. Регионоведение. Международные отношения. - 2021. - Т. 26, № 1. - С. 53-66. - DOI: https://doi.org/ 10.15688/jvolsu4.2021.1.6

Введение. Успех любой военной кампании напрямую зависит от степени боевой подготовки армейских структур и подразделений. Немаловажную роль в этом играет и фактор наличия, и уровень подготовки офицерского корпуса армии, включая его младшее унтер-офицерское звено, на которое возлагалось решение задач по работе с новобранцами, их боевой подготовке и по выполнению коммуникативных функций. В начале XIX в., в период активных военных кампаний, император Александр I принял ряд мер по расширению и совершенствованию системы подготовки младшего командного корпуса армии [31; 32; 34-36]. Одной из таких мер было создание образовательных учреждений для приготовления унтер-офицеров и военных специалистов в российских военных поселениях в 1810-1850-х годов. В учебных структурах поселенных округов из числа кантонистов - детей военных поселян - готовились младшие армейские кадры и унтер-офицеры для действующих и резервных частей. Вопросу военной подготовки резерва из числа кантонистов здесь уделялось особое внимание.

Кантонисты из военных поселян проходили подготовку, социализацию и службу практически по месту нахождения их семейств, не отрываясь от дома, как это было с солдатскими детьми, обучавшимися в батальонах и полубатальонах военных кантонистов, находившихся порой далеко от родных мест. Учитывая намерение императора со временем перевести всю армию на положение поселенных войск, образовательные структуры поселений в перспективе должны были стать основными базовыми учебными учреждениями по подготовке кадров младших офицеров.

Целью статьи является анализ опыта и результатов развития военно-учебных структур поселений на различных этапах их деятельности, что пока не нашло отражения в исследовательской практике. Актуальность темы также обусловлена расширением проблемного поля военной и культурной истории и активизацией исследований по истории образования, в том числе военного, в современной отечественной историографии.

Методы. При разработке проблематики автор использует проблемно-хронологический, источнико-ориентированный и проблемно-ориентированный подходы. В процессе анализа статистических материалов применены количественные методы (анализ динамических рядов), что позволило в частности построить трендовую модель динамики начальных образовательных структур на первом этапе развития округов кавалерии. Использование метода группировки данных сделало возможным определение структурного состава военноучебной системы поселенных округов в 18301850-х годах. На основе анализа законодательных материалов также решалась задача проведения компаративного (сравнительного) анализа подходов государства к вопросу формирования образовательных моделей, реализуемых в рамках развития военных поселений. Это позволило проследить эволюцию правитель- 
ственной политики в вопросеподготовки армейских кадров и унтер-офицерского состава исходя из менявшихся исторических реалий и выявить итоги еереализации, а также показать численный корпус выпускников учебных подразделений поселений. Определение образовательных моделей, используемых государством для социализации и подготовки к службе кантонистов поселенных полковых округов и смежных губерний, стало возможным при использовании системно-структурного подхода.

Источники. Источниками аналитического рассмотрения темы стали основополагающие законодательные документы по военным поселениям, законодательные материалы по развитию учебных учреждений поселенных округов [24; 25]. Они определяли построение и функционирование образовательной системы округов, включая специальные учебные подразделения для подготовки младших офицеров. Другие законодательные материалы регулировали развитие и учебный процесс военно-образовательных заведений поселений в конкретные периоды. Вторую группу источников представляют статистические материалы - статистические описания и таблицы по военным поселениям кавалерии за 1830 1850-е годы. Обобщающую информацию содержат также отчеты Департамента военных поселений [11-16]. Данные источники позволяют определить: количественный состав учащихся и выпускников учебных эскадронов и батарей, распределение их на службу по частям поселений и иным армейским структурам, динамику развития этих учебных подразделений, численный состав выпущенных в армию военных специалистов, а также провести сравнительный анализ по отдельным этапам развития образовательных структур.

История развития системы подготовки младшего офицерского состава нашла отражение в ряде обобщающих работ по истории армии, а также в справочно-энциклопедических изданиях [2, с. $15-56 ; 34$, с. 2$]$, в работах по истории военно-учебных заведений и по формированию кадрового состава армии [2, с. 101$185 ; 9 ; 34$, с. 2], в некоторых диссертационных исследованиях советского и постсоветского периода, включая «общие вопросы обучения и воспитания унтер-офицеров» $[2 ; 34$, с. 5]. Имеется и ряд работ по истории подготовки унтер- офицерских кадров русской армии в XIX в. [6; $26 ; 29$, с. $314-322,334-341 ; 34$, с. $2-5 ; 35 ; 36]$.

В работах дореволюционных исследователей рассматривались отдельные вопросы истории подготовки унтер-офицерского корпуса российской армии: порядок и система комплектования российских войск подготовленными кадрами, процесс комплектования армии унтер-офицерскими кадрами [26], оформление и развитие системы подготовки унтер-офицеров в карабинерных полках и специальных военно-учебных заведениях [29], проблемы организации подготовки и воспитания младших офицеров [34, с. 4]. В работе А.Ф. Редигера был осуществлен сравнительный анализ подготовки унтер-офицерского корпуса в России и отдельных европейских государствах [26]. В дореволюционный период исследователи накопили и представили определенный корпус фактографии по вопросам формирования и развития системы подготовки и комплектования унтер-офицерского корпуса армии. Но не все аспекты темы были рассмотрены в дореволюционных исследованиях общего и специального порядка. В частности, не нашла тогда полного отражения в историографии проблематика деятельности органов государственной власти и военного управления по подготовке и «по обеспечению войск унтер-офицерским кадром» $[34$, с. 4,6$]$. Она представлена в работах современного историка Э.М. Шакирзянова по истории подготовки унтер-офицерских кадров русской армии в первой половине XIX в. [34; 35]. Здесь также выявлены ее характерные черты, тенденции и особенности, показано «содержание образовательной системы подготовки унтерофицерских кадров» [34, с. 6-7].

Вне поля зрения историков также оставались вопросы комплектования поселенных войск, составлявших от четверти до трети армейского состава, младшим офицерским корпусом и другими военными специалистами в первой половине XIX века. Данная проблематика пока не разработана в полном объеме, что закономерно способствует ее актуализации в контексте развития современной историографии по проблемам формирования резервов и комплектования российской армии. Тема подготовки младших офицеров и военных специалистов в поселенной системе пред- 
ставлена лишь некоторыми сюжетами, ограниченными и в плане хронологии, в общих работах по истории военных поселений и по истории российских кантонистов (законодательство по формированию образовательных структур военных поселений; социальный статус и положение кантонистов поселений; формирование и трансформация системы начального образования кантонистов поселенных округов в 1810-1820-х гг.; изменение образовательной политики правительства в поселенных округах в 1820-х гг.) [4-6; 7, с. 99-100; 8, c. $92 ; 17$, c. $109-111 ; 36]$.

Анализ. При организации военных поселений во всех округах пехоты и кавалерии получили развитие новые образовательные структуры. Вводилось обязательное начальное образование для всех детей военных-поселян, а часть из них продолжала образование в учебных батальонах и эскадронах для подготовки к службе в качестве младших офицеров. При переходе коренных жителей в военное поселение дети их становились кантонистами, «принадлежащими на укомплектование поселенного полка», и все дети среднего и «большого» возраста «записывались в военную школу» после устройства полкового управления [23, с. 230]. Кантонисты разделялись на три возраста: «малой»- до 7 лет, средний - от 7 до 12 лет, «большой» - от 12 до 18 лет [25, с. 28]. До $12-15$ лет они находились при своих родителях или воспитателях. C 7 лет они уже носили форму и посещали ротные или эскадронные школы в селениях полковых округов [4, с. 73-76]. Начальное образование в школах строилось по ланкастерской системе. В свободное от школы время кантонисты помогали родителям в хозяйстве, усваивая навыки и «познание о земледелии».

Школьный учитель (унтер-офицер) должен был соответствовать определенным требованиям, должен быть «человек честный, беспорочного поведения, соединяющий ласковость с твердостию и знающий, как методу Ланкастера, так и разные рукоделия» для обучения кантонистов. Учитель выбирал себе помощника (старшего кантониста) «из отличнейших способностями кантонистов», одного на 20 учеников [25, с. 75; 28; 36, с. 61]. Старшие кантонисты имели должностные льготы в учебных эскадронах, возможность учиться в Военно-учительском институте (далее ВУИ) и «выпускались из него в унтер-офицеры (учители)». Имея 12 лет педагогического стажа, они могли поступать «К производству в офицеры» $[25$, с. $65-67,76]$.

В школах кантонисты занимались строевой подготовкой, рукоделием, осваивали плетение корзин и других вещей из соломы, изготовление щеток, простых моделей, ящиков, переплет книг. Для подготовки учителей-мастеровых в Москву направляли кантонистов, неспособных к строевой службе, и готовили мастеров-ремесленников в своих округах [30, л. 249 об., 293 об.-294]. По отчетам 1825 г. в Москве обучалось мастерствам 344 человека, в округах - 226 человек [15, л. 806 об., 858 , 926]. Старшие кантонисты обучались портному, сапожному, башмачному; седельному, каретному, столярному, резному, токарному, колесному, ложечному; малярному, красильному, лакировальному и басонному (позументному) ремеслам.

Динамика численности учащихся начальных школ в период с 1821 по 1832 г. Новороссийского военного поселения отражается на трендовой модели рисунка 1. Сокращение численности кантонистов в школах округов к началу 1830-х гг. было обусловлено сменой политики в отношении всех военных поселений в правление Николая I. Им был взят курс на их приоритетное развитие как хозяйственной базы армии, хотя подготовка армейских резервов не прекращалась, менялись механизмы ее реализации на базе резервных эскадронов и батальонов.

Начальные школы являлись первой ступенью приготовления кантонистов к службе в армии. Дальнейшая подготовка их проходила в специально организованных учебных батальонах и эскадронах, формировавшихся из «способных к строевой службе» кантонистов большого возраста с 12 лет. В 1821 г. изменились возрастные границы градации кантонистов, и зачисляли их в учебные эскадроны с 14 лет, с 1826 г. - с 15 лет [27, л. 475-479]. Учебный эскадрон включал 200 кантонистов и разделялся на четыре взвода (по 50 человек). В эскадроне состояли 8 унтер-офицеров учителей выпускников ВУИ [25, с. 36-38]. При отборе кантонистов в учебные эскадроны и батальоны учитывались такие факторы, как здоровье 


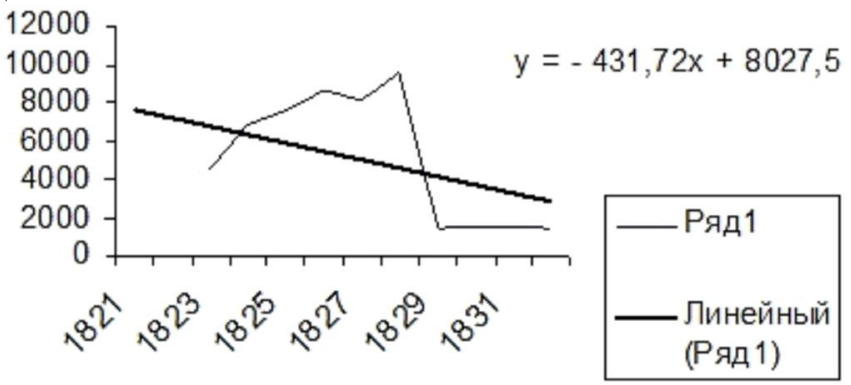

Рис. 1. Динамика численности учащихся в школах Новороссийского военного поселения 1821-1832 гг.

Fig. 1. Dynamics of the number of primary school children of the Novorossiysk military settlement in 1821-1832

Примечание. На графике представлено линейное уравнение тренда динамического ряда; среднестатистический годовой показатель сокращения численности учащихся начальных школ составляет 431 человек.

Note. The graph shows a linear equation of the trend of the dynamic series; the average annual decline in the number of primary school children is 431 .

кантониста - «крепкое сложение», наличие в семье нескольких сыновей и состоятельность поселянских хозяйств. Единственных наследников и сыновей из зажиточных хозяйств оставляли для хозяйственной деятельности, что способствовало сохранению экономического потенциала этих производственных звеньев и преемственности их развития [4, с. 77]. Часть способных кантонистов уже из школ определяли к «переводу в ВУИ». По отчету 1827 г. в Новороссийском военном поселении было выбрано к обучению в институте 12 человек [14, л. 146 об.]. Кантонисты учебных эскадронов находились на полном государственном довольствии, получали жалованье в сумме 7 руб. 50 коп. в год. На каникулы и праздники их отпускали к родителям [25, с. 41-43].

«Неспособные к строевой службе» кантонисты учебного эскадрона при выпуске отдавались «для обучения ремеслам» у мастеров, как и остальные старшие кантонисты. Пройдя трудовое обучение, они зачислялись в действующие эскадроны «в число штатных мастеровых», при отсутствии таких вакансий самостоятельно занимались ремеслом в родных селениях [25, с. 47-48]. Таким образом, все «нестроевые» кантонисты «большого» возраста (15-18 лет) в поселениях имели возможность социализации и получения профессии, позволявшей им и в дальнейшем иметь гарантированную занятость и средства к существованию. Подобная система была характерна и для учебных батальонов в поселениях пехоты. Однако здесь формирование этих образовательных структур в 1820-х гг. шло не так активно, как в поселениях кавалерии. По отчету 1824 г. существовал «один только Учебный баталион в округе Гренадерского графа Аракчеева полка, образованный во всем на правилах Высочайше конфирмованного в 7-й день июня 1823 года Положения», тогда как учебные дивизионы (объединенные эскадроны) были тогда уже во всех округах поселения кавалерии [16, с. 22].

Образование кантонистов в специальных учебных подразделениях включало три составляющие и имело комплексный характер: военная подготовка, общеобразовательное обучение, трудовая деятельность [22]. Воспитание разделялось «на воспитание физическое, имеющее целью сбережение и подкрепление здоровья», и физическое развитие, и на воспитание нравственное, которое должно было образовывать их к добродетели и благочестию и пеклось о душе, отвращало от зла, «наклоняло к добру» и поселяло «чувства, соделывающие их полезными обществу» [25, с. 54-55, 60-62]. Курс военной подготовки строился на основе курса рекрутской школы. На все занятия кантонистов отводилось по 11 часов в день. Военные занятия продолжались по 3 часа в день, занятия ремеслами или обработка сада и огорода - 4 часа $[25$, с. 56-58, 59]. Общий курс изначально составляли предметы: закон Божий, русский язык, арифметика, первоначальные понятия о геометрии, черчение, рисование и пение [25, с. 69, 73]. По положению 1826 г. были прибавлены новые учебные курсы - чистописание, судопроизводство, бухгалтерский учет [4, с. 77]. Осваивая эти курсы, кантонисты по- 
ступали на службу в структуры поселенного управления. В процессе обучения они осваивали практический опыт и навыки, необходимые по службе [25, с. $70-71]$.

По окончании обучения в 18 лет кантонисты поступали на службу в полки поселений и служили практически дома или рядом с домом. Показатели (естественная выборка) по выпускам кантонистов на службу в Новороссийском военном поселении представлены в таблице 1. В 1823 г. на службу в целом в действующие батальоны и эскадроны поступило 1160 человек [16, с. 22-23]. Распределение выпускников по подразделениям поселений определялось их потребностями в служащих.

В 1826 г. было принято новое «Положение об учебном эскадроне...» [22]. Основные принципы его формирования и развития были сохранены: состав - 200 кантонистов, 4 взвода, полное казенное содержание, проживание в казарме эскадрона, три основных составляющих образовательного процесса, деление на три класса «по наукам». В документ добавили план учебных предметов по классам, состав руководства эскадрона увеличивался, вводилась должность инспектора классов. Прием в эскадрон осуществлялся теперь с 15 лет. Военная подготовка включала обучение пешему и конному строю, верховой езде, фехтование, рубку саблями и фланкирование пиками [22, л. 276-280]. Летом 1826 г. была подготовлена записка генерала графа И.О. Витта об учреждении юнкерской школы в поселенном корпусе кавалерии. Отмечая не- достаток образованных офицеров в армейских полках, который «более еще ощущается в военном поселении», так как оно требует значительного числа чиновников с познаниями по различным частям - строительной, экономической, управлению дежурствами и командиров, которые должны иметь «основательные сведения» потому, что им подчинялись и эскадронные школы, он предлагал учредить школу для «образования молодых дворян, поступающих на службу без соответствующих знаний», и кантонистов. В комплект школе предполагалось: 40 портупей юнкеров и юнкеров и 60 кантонистов. Кантонисты после окончания выпускались бы в полковые и дивизионные штабы кондукторами или в полковые школы учителями [1, л. 392-393 об.]. Позднее проект был реализован с некоторыми изменениями.

Первый этап развития поселений был завершен в 1826-1827 гг., когда была проведена реформа. Менялся подход к организации поселенной системы и, как следствие, к построению образовательных структур [19; 20; 31, с. 524 $525,530-531 ; 36$, с. 64]. Учебные подразделения упразднялись, обучение кантонистов переходило в строевые резервные батальоны и дивизионы поселений. Новая учебная система вводилась с начала 1827 г. [18, л. 204-206]. В резервном батальоне пешего полка состояли по штату 552 кантониста, в резервном эскадроне по 70 кантонистов, а в трех эскадронах -210 [31, c. XX, LIII-LIV]. Обучение начиналось с 16 лет, и учились они 4 года, проживая в домах родителей. Курс общего обучения ограничивался те-

\section{Таблица 1. Распределение выпускников учебных эскадронов Новороссийского (Хер- сонского) военного поселения 1821-1826 гг.}

Table 1. Distribution of graduates of training squadrons of the Novorossiysk (Kherson) military settlement in 1821-1826

\begin{tabular}{|c|c|c|c|c|}
\hline $\begin{array}{c}\text { Год выпуска } \\
\text { кантонистов } \\
\text { большого возраста }\end{array}$ & $\begin{array}{c}\text { На службу } \\
\text { в поселенные } \\
\text { эскадроны }\end{array}$ & $\begin{array}{c}\text { На службу } \\
\text { в резервные } \\
\text { эскадроны }\end{array}$ & $\begin{array}{c}\text { На службу } \\
\text { в действующие } \\
\text { эскадроны }\end{array}$ & $\begin{array}{c}\text { В инвалидные команды } \\
\text { своего полка / } \\
\text { в нестроевые полка }\end{array}$ \\
\hline 1821 г. & $65(11,28 \%)$ & $346(60,06 \%)$ & $154(26,73 \%)$ & $11(1,9 \%) /-$ \\
\hline 1823 г. & нет данных & нет данных & 466 & $-/-$ \\
\hline 1825 г. & $122(11,41 \%)$ & $834(78,02 \%)$ & $78(7,29 \%)$ & $\begin{array}{c}34 / 1 \\
(3,18 \%) /(0,09 \%)\end{array}$ \\
\hline 1826 г. & $137(12,49 \%)$ & $918(83,68 \%)$ & $28(2,55 \%)$ & $\begin{array}{c}13 / 1 \\
(1,18 \% /(0,09 \%)\end{array}$ \\
\hline Всего & $324(10,13 \%)$ & $2098(65,62 \%)$ & $726(22,7 \%)$ & $\begin{array}{c}47 / 2 \\
(1,47 \% / 0,06 \%)\end{array}$ \\
\hline
\end{tabular}

Примечание. Составлено по: [13; 15; 16;30]. 
перь такими предметами, как чтение, письмо, арифметика. При проведении реформы были ликвидированы 14 учебных батальонов и 20 эскадронов [36, с. 64].

В 1836 г. в связи с потребностью «для доставления полкам и артиллерийским батареям, постоянно квартирующим в округах военного поселения, более способов к укомплектованию унтер-офицерами и фейерверкерами» было принято решение о сформировании учебных эскадронов, по два на округ (дивизион), и батарей, по одной на поселенную дивизию [21, с. $871-875 ; 32$, с. 291,$301 ; 33$, док. № 1, с. 45]. Они готовили для резервной кавалерии образованных рядовых «для назначения впоследствии по способности в унтер-офицеры и фейерверкеры». В 1849 г. насчитывалось 24 учебных дивизиона или 48 эскадронов и 6 батарей $[10$, с. 357]. Эскадроны и батареи формировались из кантонистов эскадронных школ поселений, кантонистов - детей военных поселян, кроме усыновленных, и кантонистов Екатеринославского и Херсонского батальонов и Дмитриевского полубатальона, в том числе находящихся при родителях [21, с. 872]. Зачисляли кантонистов с 14 лет и старше. По шта- ту в эскадроне обучалось по 120 кантонистов, в батарее - по 136 человек, реально численность их была больше. В учебном дивизионе могло обучаться до 270-290 кантонистов, а в батареях - от 167 до 292 кантонистов. Численность кантонистов в 1830-1850-х гг. в учебных эскадронах и батареях почти в 1,5 превышала таковую в 1810-1820-х гг. [33, док. № 1, с. 46 , док. № 27 , с. 199 , док. № 28 , с. 246 , док. № 30, с. 280]. Отмечались случаи подготовки артиллеристов при батареях резервных корпусов. В 1847 г. при легких № 11 и 17 батареях Украинского военного поселения обучались 2 кантониста [33, док. № 2, с. 70].

Помимо учебных эскадронов и батарей в поселениях были учреждены школы: топографов, кондукторские, фельдшерские, коновальские (ветеринарные), сельскохозяйственные, берейторские, где обучали кантонистов правилам выездки лошадей. Группировка кантонистов по профилям подготовки представлена на диаграмме рисунка 2 и в пояснениях. Большая часть кантонистов (79 \%) готовилась к армейской службе в учебных эскадронах и батареях. Общее число детей и кантонистов учебных возрастов в Украинских поселениях

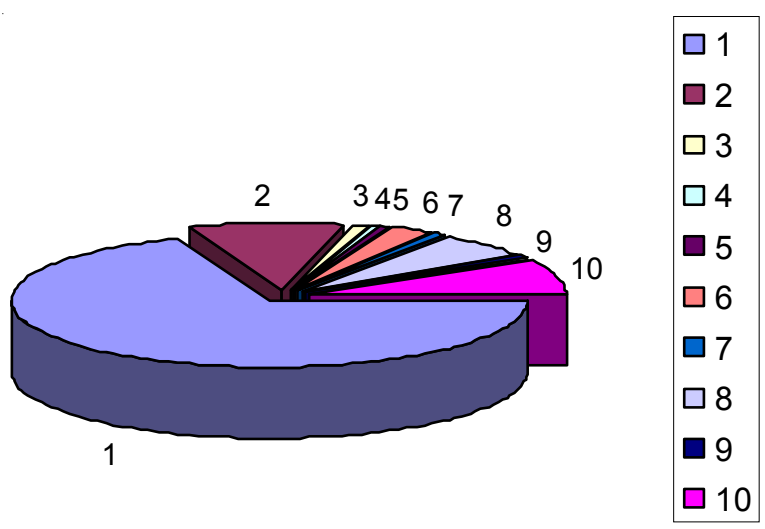

Рис. 2. Распределение учащихся кантонистов по образовательным программам в Украинском военном поселении. 1847 г.:

1 - в учебных эскадронах - 1823 чел. (69 \%); 2 - в учебных батареях - 259 чел. (10\%); 3 - в рабочем батальоне - 27 чел. (1,02\%); 4 - в школе «топографских учеников» - 10 чел. $(0,4 \%)$;

5 - в кондукторской школе - 15 чел. (1\%); 6 - готовятся в писаря - 80 чел. (3\%);

7 - готовятся в учителя - 21 чел. $(0,8 \%) ; 8$ - в фельдшерских школах - $152(6 \%)$;

9 - в коновальских школах - 31 чел. (1,17\%); 10 - обучаются мастерствам - 217 чел. (8 \%)

Fig. 2. Distribution of Cantonese students by educational programs in the Ukrainian military settlement in 1847:

1 - in training squadrons $-1,823$ people $(69 \%) ; 2$ - in training batteries -259 people $(10 \%)$;

3 - in a working battalion - 27 people $(1.02 \%) ; 4$ - in the school of "topographical students" - 10 people $(0.4 \%)$;

5 - in the conductor's school - 15 people (1\%); 6 - preparing to become a clerk (copyist) - 80 people (3\%);

7 - preparing to become a teacher - 21 people $(0.8 \%) ; 8$ - in medical assistant (feldsher) schools - $152(6 \%)$;

9 - in horse doctor (konoval) schools -31 people $(1.17 \%) ; 10$ - training in masteries -217 people $(8 \%)$ 
в 1847 г. составляло 3959 человек. Обучались в учебных заведениях округов 2695 кантонистов $(68,08 \%)$ и 1264 человека $(31,92 \%)$ не были включены в процесс образования, а были заняты в хозяйствах. Выпускники 1847 г. и другие кантонисты были отправлены к местам службы: в действующие полки - 174 человека $(41,92 \%)$, в иные полки и команды $92(22,16 \%)$, в рабочий батальон - $4(0,96 \%)$, в нестроевые должности - 25 (6,02\%), в инвалиды округов - 36 человек $(8,67 \%)$. На обучение в учебные эскадроны и батареи определялись 52 кантониста $(12,53 \%)$, в школьники военных госпиталей -21 (5,06 \%), в приказы общественного призрения - 1 кантонист $(0,24 \%)$. Для призрения родственников были направлены 10 кантонистов $(2,4 \%)$, что предусматривалось правилами опеки в поселениях [33, док. № 2, с. 70-71].

Учебный курс 1836 г. состоял из занятий по фронту и образования в классах. При каждом эскадроне позволялось обучать мастерствам не более 15 человек и при батаpeе не более 10 из не способных к службе старших кантонистов. Их обучали портному, сапожному, седельному, столярному, колесному, ложечному, кузнечному, малярному и оружейному мастерствам. По фронту кантонистов учили правильной выправке, маршировке, знанию рекрутской школы, фланкированию и рубке саблями, аванпостной службе, сигналам, верховой езде, «а также ученью пешему - по конному, эскадронному и полковому»; а в батареях - и действию при орудиях $[21$, с. $873 ; 33$, док. № 2, с. 46]. Они определялись на службу рядовыми в свои полки и батареи, а через три года могли производиться в унтер-офицеры и фейерверкеры. Отличников разрешалось производить в младшие офицеры через полгода службы. Кантонисты-мастеровые определялись в полки и батареи [21, с. 874]. В 1841 г. учебные эскадроны сформировали и в Киевско-Подольском военном поселении [3, с. 75].

С основания и до 1856-1857 гг. из 40 учебных эскадронов и 5 учебных батарей было выпущено значительное количество подготовленных служащих в резервные кавалерийские корпуса. Группировки распределения выпусков представлены в таблице 2 и на рисунках $3-$ 6. Первый выпуск в резервные корпуса про- шел в 1840 г. и составлял 755 готовых к службе кантонистов [12, л. 44]. Ранее, в 1838 г. было «выбрано 200 чел. из батарей на укомплектование Донской конной артиллерии» [11, л. 74 об.]. По данным таблицы 2, среднегодовой выпуск в полки и батареи составлял 934 человека, подготовленных к службе и в перспективе к переходу в унтер-офицерское звание (16 выпусков, 1840-1856/57 гг.).

Результаты. На основе анализа развития образовательных структур поселенных округов в период 1810-1850-х гг. определяется положение о смене подходов правительства к вопросу обучения и воспитания кантонистов военных поселений и механизмов их систематизации и реализации в это время. В периодизации развития системы военного образования поселений и подготовки унтер-офицерских кадров четко выделяются три этапа: 1) с 1816-1817 по 1826 г.; 2) с 1827 по 1836 г. и 3) с 1836 по 1857 год. В этом заключалось ее отличие от периодизации развития общеармейской системы подготовки унтер-офицерского корпуса, где исследователями выделены два этапа: 1) 18081825 гг.; 2) 1825-1855 гг. [34, с. 15-18]. Системная подготовка армейских резервов на базе специально сформированных образовательных структур - учебных эскадронов, батарей и батальонов (до 1826 г.) оказалась более эффективной, чем подготовка их в строевых резервных частях (1827-1836 гг.), о чем свидетельствует отказ от данной образовательной модели в 1836 г. и возврат (с определенными трансформациями) к первоначальной модели 1810-х годов. Одновременно происходило увеличение числа учебных эскадронов и батарей для подготовки младшего армейского и унтерофицерского состава более чем в 2 раза и соответственно умножение численности обучаемого в них кантонистского корпуса и выпускников. При этом сохранялось двуединство или два уровня образовательной системы поселенных округов для подготовки армейских специалистов: начальные школы - учебные эскадроны (дивизионы) и батареи или специальные учебные заведения (кондукторские, топографические, фельдшерские, ветеринарные, берейторские и другие школы) и обучение мастерствам. В общеармейской системе подготовки унтер-офицеров на данном этапе предусматривалось три уровня [34, с. 17-18]. 
T.Н. Кандаурова. Подготовка армейских резервов в учебных структурах военных поселений

Таблица 2. Распределение выпускников учебных эскадронов и батарей военных поселений кавалерии в 1836-1857 гг. и количественный состав учащихся в 1856-1857 гг.

Table 2. Distribution of graduates of training squadrons and batteries of the cavalry military settlement in 1836-1857 and the quantitative composition of students in 1856-1857

\begin{tabular}{|c|c|c|c|c|c|c|c|c|}
\hline \multirow{2}{*}{$\begin{array}{c}\text { Региональное } \\
\text { военное } \\
\text { поселение }\end{array}$} & \multirow{2}{*}{$\begin{array}{c}\text { Выпущено в } \\
\text { полки и бата- } \\
\text { реи на службу }\end{array}$} & \multirow{2}{*}{$\begin{array}{l}\text { Произведе- } \\
\text { но в унтер- } \\
\text { офицеры }\end{array}$} & \multirow{2}{*}{$\begin{array}{l}\text { Произведе- } \\
\text { но в фейер- } \\
\text { веркеры }\end{array}$} & \multirow{2}{*}{$\begin{array}{c}\text { Поступило } \\
\text { в нестроевые } \\
\text { и писари }\end{array}$} & \multicolumn{2}{|c|}{$\begin{array}{c}\text { Состоит } \\
\text { в 1856-1857 гг. } \\
\text { в эскадронах }\end{array}$} & \multicolumn{2}{|c|}{$\begin{array}{c}\text { Состоит } \\
\text { в } 1856-1857 \text { гг. } \\
\text { в батареях }\end{array}$} \\
\hline & & & & & $\begin{array}{c}\text { нижних } \\
\text { чинов }\end{array}$ & $\begin{array}{l}\text { канто- } \\
\text { нистов }\end{array}$ & $\begin{array}{c}\text { нижних } \\
\text { чинов }\end{array}$ & $\begin{array}{l}\text { канто- } \\
\text { нистов }\end{array}$ \\
\hline $\begin{array}{l}\text { Украинское во- } \\
\text { енное поселение } \\
1856 \text { г. }\end{array}$ & $\begin{array}{c}6659 \\
(44,52 \%)\end{array}$ & $\begin{array}{c}527 \\
(36,34 \%)\end{array}$ & $96(53,0 \%)$ & $\begin{array}{c}608 \\
(32,27 \%)\end{array}$ & 278 & 2165 & 25 & 291 \\
\hline $\begin{array}{l}\text { Киевско-По- } \\
\text { дольское воен- } \\
\text { ное поселение } \\
1856 \text { г. }\end{array}$ & $1270(8,49 \%)$ & $108(7,44 \%)$ & Нет & $\begin{array}{c}\text { В писари } \\
242 \\
(12,84 \%)\end{array}$ & 138 & 1080 & Нет & Нет \\
\hline $\begin{array}{l}\text { Новороссийское } \\
\text { военное поселе- } \\
\text { ние 1-8 округа } \\
1857 \text { г. }\end{array}$ & $\begin{array}{c}4468 \\
(29,87 \%)\end{array}$ & $\begin{array}{c}489 \\
(33,51 \%)\end{array}$ & $\begin{array}{c}51 \\
(28,17 \%)\end{array}$ & $\begin{array}{c}627 \\
(33,28 \%)\end{array}$ & 298 & 2215 & 27 & 314 \\
\hline $\begin{array}{l}\text { Новороссийское } \\
\text { военное поселе- } \\
\text { ние 9-12 округа } \\
1857 \text { г. }\end{array}$ & $\begin{array}{c}2561 \\
(17,12 \%)\end{array}$ & $\begin{array}{c}326 \\
(22,48 \%)\end{array}$ & $\begin{array}{c}34 \\
(18,78 \%)\end{array}$ & $\begin{array}{c}407 \\
(21,6 \%)\end{array}$ & 150 & 1080 & 29 & 292 \\
\hline $\begin{array}{l}\text { Всего по Ново- } \\
\text { российскому во- } \\
\text { енному поселе- } \\
\text { нию } 1857 \text { г. }\end{array}$ & $\begin{array}{c}7029 \\
(46,99 \%)\end{array}$ & $\begin{array}{c}815 \\
(56,20 \%)\end{array}$ & $\begin{array}{c}85 \\
(46,96 \%)\end{array}$ & $\begin{array}{c}1034 \\
(54,88 \%)\end{array}$ & 448 & 3295 & 56 & 606 \\
\hline $\begin{array}{l}\text { Всего по воен- } \\
\text { ным поселениям } \\
\text { кавалерии }\end{array}$ & 14958 & 1450 & 181 & 1884 & & & & \\
\hline
\end{tabular}

Примечание. Составлено по: [33, док. № 2, с. 46, док. № 27, с. 172-173, док. № 28, с. 223, док. № 30, с. 280].

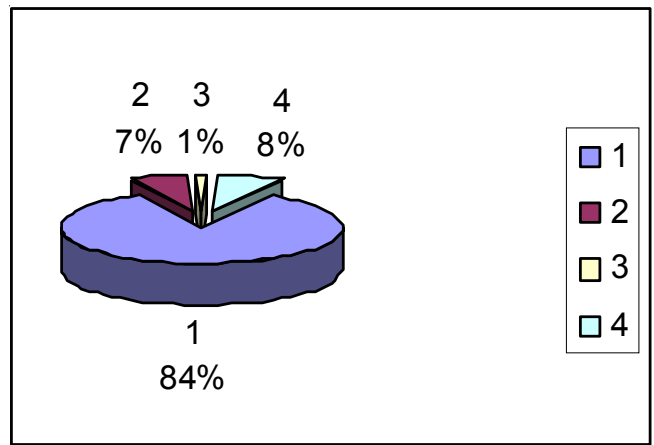

Рис. 3. Распределение выпускников учебных эскадронов и батарей по Украинскому военному поселению 1836-1856 гг:

1 - выпущено в полки и батареи на службу; 2 - произведено в унтер-офицеры;

3 - произведено в фейерверкеры; 4 - поступило в нестроевые и писари

Fig. 3. Distribution of graduates of training squadrons and batteries in the Ukrainian military settlement in 1836-1856:

1 - released into regiments and batteries for service; 2 - promoted to non-commissioned officers;

3 - promoted to non-commissioned officers in the artillery; 4 - entered the service of non-combatants and clerks (copyists) 


\section{ВООРУЖЕННЫЕ СИЛЫ И ВОЕННЫЕ ДЕЙСТВИЯ}

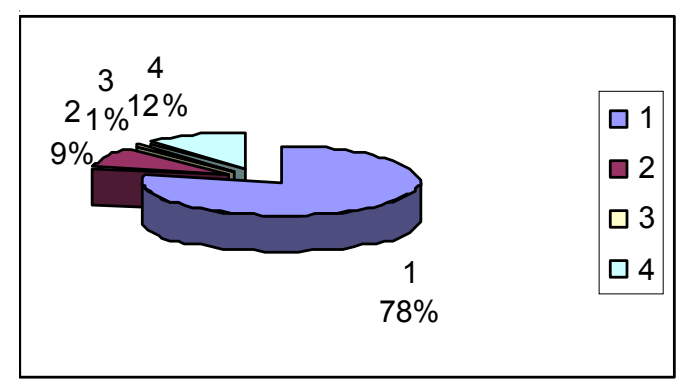

Рис. 4. Распределение выпускников учебных эскадронов и батарей по Новороссийскому военному поселению 1836-1857 гг.:

1 - выпущено в полки и батареи на службу; 2 - произведено в унтер-офицеры;

3 - произведено в фейерверкеры; 4 - поступило в нестроевые и писари

Fig. 4. Distribution of graduates of training squadrons and batteries in the Novorossiysk military settlement in 1836-1857:

1 - released into regiments and batteries for service; 2 - promoted to non-commissioned officers;

3 - promoted to non-commissioned officers in the artillery; 4 - entered the service of non-combatants and clerks (copyists)

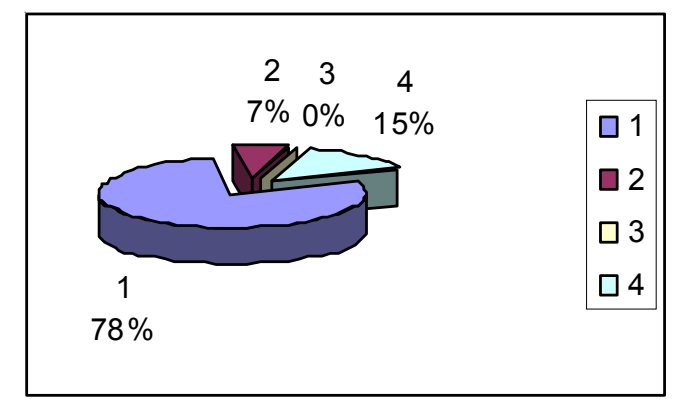

Рис. 5. Распределение выпускников учебных эскадронов по Киевско-Подольскому военному поселению 1841-1856 гг.:

1 - выпущено в полки и батареи на службу; 2 - произведено в унтер-офицеры;

3 - произведено в фейерверкеры; 4 - поступило в нестроевые и писари

Fig. 5. Distribution of graduates of training squadrons in the Kiev-Podolsk military settlement in 1841-1856:

1 - released into regiments and batteries for service; 2 - promoted to non-commissioned officers;

3 - promoted to non-commissioned officers in the artillery; 4 - entered the service of non-combatants and clerks (copyists)

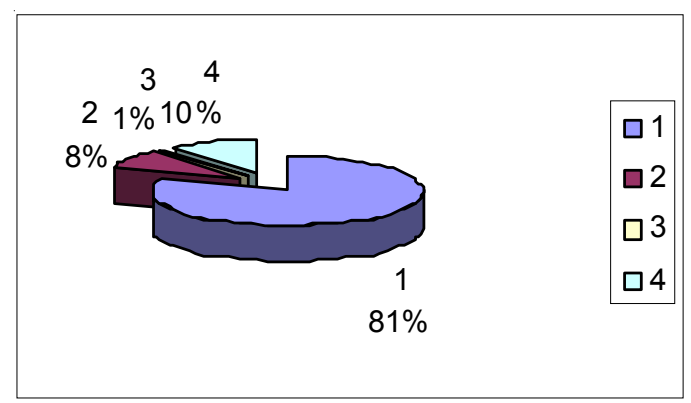

Рис. 6. Распределение выпускников учебных эскадронов и батарей по военным поселениям кавалерии 1836-1857 гг:

1 - выпущено в полки и батареи на службу; 2 - произведено в унтер-офицеры;

3 - произведено в фейерверкеры; 4 - поступило в нестроевые и писари

Fig. 6. Distribution of graduates of training squadrons and batteries in military settlements of the cavalry in $1836-1857$ :

1 - released into regiments and batteries for service; 2 - promoted to non-commissioned officers;

3 - promoted to non-commissioned officers in the artillery; 4 - entered the service of non-combatants and clerks (copyists) 
Соотношение среднегодовых показателей выпусков унтер-офицеров из учебных эскадронов и батарей военных поселений (таблица 2; 102 унтер-офицера) и общеармейских учебных подразделений (531 унтер-офицер) $[34$, с. 20] в период правления Николая I составляло 1 (16,11\%) : 5,2 (83,88 \%). Практически $1 / 6$ часть унтер-офицеров российской армии обучалась и готовилась для армейской службы в поселенных полковых округах, и они пополняли младший офицерский штат поселенных частей (6 кавалерийских дивизий и конно-артиллерийская бригада) и других структур, включая рабочие батальоны, трех резервных армейских корпусов.

Расширение и структурное обновление образовательной системы военных поселений осуществлялось по мере возникновения потребности поселенных полков и резервных частей в специалистах. В конце 1820-1850-х гг., как показано в таблице 2 и диаграммах, в нее были интегрированы новые специальные учебные заведения. При подготовке кантонистов использовались европейские методики и образовательные практики - система Белла-Ланкастера, И.Г. Пестолоцци $[25$, с. $70-71]$ и комплексный подход в построении учебных курсов (общее, специальное и трудовое обучение). Развитие образовательных структур поселений способствовало также расширению подготовки педагогических кадров как военного, так и гражданского профиля и появлению Военно-учительского института, выпускавшего преподавателей для округов военных поселений. Действующие и резервные части поселений, пополняемые в том числе и выпускниками учебных эскадронов и батальонов, хорошо зарекомендовали себя в военных кампаниях 1820-1830-х гг. (русско-турецкая война 1828-1829 гг., Бугская уланская дивизия; польская кампания 1830-1831 гг., Гренадерский корпус и 3-й Резервный кавалерийский корпус графа И.О. Витта).

\section{СПИСОК ЛИТЕРАТУРЫ}

1. Записка генерал-лейтенанта графа Витта об учреждении юнкерской школы в поселенном кавалерийском корпусе // Российский государственный военно-исторический архив (РГВИА). - Ф. 405. Оп. 1. - Д. 408. - Л. 392-398.
2. Изонов, В. В. Подготовка военных кадров в России: ХІХ - начало XX в. : дис. ... д-ра ист. наук / Изонов Виктор Владимирович. - СПб., 1998. $755 \mathrm{c}$.

3. Именной указ о сформировании в округах Киевской и Подольской губерний эскадронов кантонистов // Полное собрание законов Российской империи (ПСЗ РИ-2). - Т. XVI. - № 15069. - Спб. : Тип. ІІ Отд-ния С. Е. И. В. канцелярии, 1842.

4. Кандаурова, Т. Н. Система образования в военных поселениях России в XIX в. / Т. Н. Кандаурова // Педагогика. - 2000. - № 7. - С. 73-78.

5. Кандаурова, Т. Н. Система подготовки кадров для военных поселений в России: военно-учительские институты первой половины XIX века / Т. Н. Кандаурова // Наука и техника: вопросы истории и теории : материалы XXIV годичной конференции Санкт-Петербургского отделения Российского национального комитета по истории и философии науки и техники «Санкт-Петербург и мировая наука» (23-27 июня 2003 г.). - СПб. : С.-Петерб. науч. центр РАН, 2003. - Вып. ХІХ. - С. 306-309.

6. Кандаурова, Т. Н. Подготовка армейских кадров в системе учебных заведений кантонистов: по материалам Департамента военных поселений / Т. Н. Кандаурова // Документ. Архив. История. Современность : сб. науч. тр. / гл. ред. Л. Н. Мазур. - Екатеринбург : Изд-во Урал. ун-та, 2019. - Вып. 19. - С. 346-365.

7. Карцов, П. О военных поселениях при графе Аракчееве / П. Карцов // Русский вестник. 1890. - Кн. 3. - № 3. - С. 82-113.

8. Лыкошин, А. С. Военные поселения / А. С. Лыкошин // Великая реформа. Русское общество и крестьянский вопрос в прошлом и настоящем. - М. : Т-во И. Д. Сытина, 1911. - Т. 2. - С. 86-106.

9. Невзоров, Е. Ю. Солдатские дети как успешный проект формирования резерва комплектования русской армии в первой половине XIX века /Е. Ю. Невзоров // Вестник Тамбовского ун-та. Серия: Гуманитарные науки. - 2019. - Т. 24, № 180.C. 133-141.

10. Обзор учебных заведений военных кантонистов и учебных карабинерных полков // Документ. Архив. История. Современность : сб. науч. тр. / гл. ред. Л. Н. Мазур. - Екатеринбург : Изд-во Урал. ун-та, 2019. - Вып. 19. - С. 356-359.

11. Отчет Департамента военных поселений за 1838 г. // РГВИА. - Ф. 405. - Оп. 10. - Д. 155. - 156 л.

12. Отчет Департамента военных поселений за 1840 г. // РГВИА. - Ф. 405. - Оп. 10. - Д. 251. - 119 л.

13. Отчет по 3-й и Бугской поселенным уланским дивизиям за минувший 1821 год // РГВИА. Ф. 405. - Оп. 1. - Д. 140. - Л. 620-643.

14. Отчет по 3-й Уланской поселенной дивизии за 1827 г. // РГВИА. - Ф. 405. - Оп. 2. - Д. 771. Л. $140-158$. 
15. Отчеты по Бугской и 3-й уланским и 3-й Кирасирской дивизиям за 1825 г. // РГВИА. -Ф. 405. Оп. 1. - Д. 407. - Л. 790-961.

16. Отчет по военным поселениям за 1824 год. - Спб. : Тип. Штаба военных поселений, 1825. $-153 \mathrm{c}$.

17. Петров, А. Н. Устройство и управление военными поселениями в России / А. Н. Петров // Граф Аракчеев и военные поселения. 1809-1831. Спб. : Русская старина, 1871. - С. 87-193.

18. Положение и приказ о учебном дивизионе в округе военного поселения кавалерийского полка // РГВИА. - Ф. 405. - Оп. 1. - Д. 407. - Л. 204-206.

19. Положение о полном составе поселенного пешего полка и его обязанностях. - Спб. : Тип. Гл. штаба Е. И. В. по военному поселению, 1826. - 39 с.

20. Положение о военном поселении регулярной кавалерии. - Спб. : Тип. Гл. штаба Е. И. В. по военному поселению, 1827. - 77 с.

21. Положение о сформировании из военных кантонистов кавалерийских эскадронов и артиллерийских батарей в округах военного поселения кавалерии // ПСЗ РИ-2. - Спб. : Тип. ІІ Отд-ния С. Е. И. В. канцелярии, 1837. - Т. ХІ. - № 9466. - С. 871-878.

22. Положение об учебном эскадроне в округе поселенного кавалерийского полка // РГВИА. Ф. 405. - Оп. 1. - Д. 382. - Л. 245-320.

23. Правила о переходе коренных жителей в военное поселение округа военного поселения кавалерии // Граф Аракчеев и военные поселения. 18091831. - Спб. : Русская старина, 1871. - С. 228-232.

24. Проект Учреждения о военном поселении пехоты. Ч. 1-3. - Спб. : Тип. К. Крайя, 1817. - 261 с.

25. Проект Учреждения о военном поселении регулярной кавалерии. Ч. 2. - Спб. : Тип. К. Крайя, 1817. $-96 \mathrm{c}$.

26. Редигер, А. Унтер-офицерский вопрос в главных европейских армиях / А. Редигер. - Спб. : Тип. Тренке и Фюсно, $1880 .-188$ с.

27. Рескрипты Александра I Аракчееву и конфирмованные доклады и предложения его за 1821 г. // РГВИА. - Ф. 405. - Оп. 1. - Д. 88. - 909 л.

28. Руководство к учреждению школ для кантонистов среднего возраста по методе взаимного обучения и к управлению оными. - Спб. : б. и., 1819. -94 c.

29. Русская военная сила. История развития военного дела от начала Руси до нашего времени / под ред. А. Н. Петрова. - М. : Типо-Литография И.Н. Кушнерева и Ко, 1892. - Т. 2. - 569 с.

30. Сведения к отчету по военным поселениям за 1826 год// РГВИА. - Ф. 405. - Оп. 2. - Д. 155. 336 л.

31. Хроника российской императорской армии, составленная по высочайшему повелению. Ч. IV. - Спб. : Военная типография, 1852. -611 с.
32. Хроника российской императорской армии, составленная по высочайшему повелению. Ч. V. - Спб. : Военная типография, 1852. -533 с.

33. Цубенко, В. Л. Документи из історії військових поселень в Україні / В. Л. Цубенко. Харків : Видавництво САГА, 2008. - 374 с.

34. Шакирзянов, Э. М. Подготовка унтер-офицерских кадров русской армии в первой половине XIX в.: историческое исследование : автореф. ... дис. канд. ист. наук / Шакирзянов Эдуард Мансурович. М., 2011.-24 c.

35. Шакирзянов, Э. М. Становление системы подготовки унтер-офицерских кадров русской армии в первой половине XIX в. / Э. М. Шакирзянов // Вестн. Воен. ун-та. - 2010. - № 1 (21). - С. 46-56.

36. Ячменихин, В. К. Институт военных кантонистов в структуре русской армии / В. К. Ячменихин // Вестн. Моск. ун-та. - Серия 8, История. 2000. - № 1. - C. 55-68.

\section{REFERENCES}

1. Zapiska general-leytenanta grafa Vitta ob uchrezhdenii yunkerskoy shkoly v poselennom kavaleriyskom korpuse [Note by Lieutenant General Count Witt on the Establishment of the Junker School in the Settled Cavalry Corps]. Rossiyskiy gosudarstvennyy voyenno-istoricheskiy arkhiv (RGVIA) [Russian State Military Historical Archive], f. 405, inv. 1, d. 408, 1. 392-398.

2. Izonov V.V. Podgotovka voennykh kadrov v Rossii: XIX - nachalo XX v.: dis. d-ra ist. nauk [Training of Military Personnel in Russia: XIX - Early XX Centuries. Dr. hist. sci. diss.]. Saint Petersburg, 1998. $755 \mathrm{p}$.

3. Imennoy ukaz o sformirovanii v okrugakh Kiyevskoy i Podol'skoy guberniy eskadronov kantonistov [A Personal Decree on the Formation of Cantonese Squadrons in the Districts of Kiev and Podolsk Provinces]. Polnoye sobraniye zakonov Rossiyskoy imperii (PSZ RI-2) [The Complete Collection of Laws of the Russian Empire (PSZ RI-2)]. Vol. XVI. No. 15069. Saint Petersburg, Tipografiya II Otdeleniya S. E. I. V. kantselyarii, 1842.

4. Kandaurova T.N. Sistema obrazovaniya $v$ voennykh poseleniyakh Rossii v XIX v. [Educational System in Military Settlements of Russia in the XIX Century]. Pedagogika [Pedagogy], 2000, no. 7, pp. 73-78.

5. Kandaurova T.N. Sistema podgotovki kadrov dlya voennykh poselenii v Rossii: voenno-uchitel'skie instituty pervoi poloviny XIX veka [Personnel Training System for Military Settlements in Russia: Military Teaching Institutes of the First Half of the XIX Century]. Nauka i tekhnika: voprosy istorii $i$ 
teorii: materialy XXIV godichnoi konferentsii SanktPeterburgskogo otdeleniya Rossiiskogo natsional'nogo komiteta po istorii i filosofii nauki $i$ tekhniki «Sankt-Peterburg i mirovaya nauka» (2327 iyunya 2003 g.) [Science and Technology: Questions of History and Theory. Proceedings of the $24^{\text {th }}$ Annual Conference of the Saint Petersburg Branch of the Russian National Committee for the History and Philosophy of Science and Technology "Saint Petersburg and World Science" (June 23-27, 2003)]. Saint Petersburg, Sankt-Peterburgskiy nauchnyy tsentr RAN, 2003, iss. XIX, pp. 306-309.

6. Kandaurova T.N. Podgotovka armeiskikh kadrov v sisteme uchebnykh zavedenii kantonistov: po materialam Departamenta voennykh poselenii [Training of Army Personnel in the System of Cantonese Educational Institutions: Based on the Materials of the Department of Military Settlements]. Mazur L.N., ed. Dokument. Arkhiv. Istoriya. Sovremennost: sb. nauch. tr. [Document. Archive. History. Modernity: Collection of Proceedings]. Yekaterinburg, Izd-vo Uralskogo universiteta, 2019, iss. 19, pp. 346-365.

7. Kartsov P. O voennykh poseleniyakh pri grafe Arakcheeve [On the Military Colonies Under Count Arakcheev]. Russkii vestnik [Russian Bulletin], 1890, book 3, no. 3, pp. 82-113.

8. Lykoshin A.S. Voennye poseleniya [Military Settlement]. Velikaya reforma. Russkoe obshchestvo $i$ krest'yanskii vopros v proshlom i nastoyashchem [Great Reform. Russian Society and the Peasant Question in the Past and Present]. Moscow, Tovarishchestvo I.D. Sytina, 1911, vol. 2, pp. 86-106.

9. Nevzorov E.Yu. Soldatskie deti kak uspeshnyi proekt formirovaniya rezerva komplektovaniya russkoi armii v pervoi polovine XIX veka [Soldiers' Children as a Successful Project of Forming the Reserve of the Russian Army in the First Half of the XIX Century]. Vestnik Tambovskogo un-ta. Seriya: Gumanitarnye nauki [Bulletin of the Tambov University], 2019, vol. 24, no. 180, pp. 133-141.

10. Obzor uchebnykh zavedeniy voyennykh kantonistov i uchebnykh karabinernykh polkov [Review of Educational Institutions of the Military Cantonists and Training Carabinier Regiments]. Mazur L.N., ed. Dokument. Arkhiv. Istoriya. Sovremennost: sb. nauch. tr. [Document. Archive. History. Modernity: Collection of Proceedings]. Yekaterinburg, Izd-vo Ural. un-ta, 2019, iss. 19 , pp. 356-359.

11. Otchet Departamenta voyennykh poseleniy za 1838 g. [Report of the Department of Military Settlements for 1838]. RGVIA [Russian State Military Historical Archive], f. 405, inv. 10, d. 155. 1561.

12. Otchet Departamenta voyennykh poseleniy za 1840 g. [Report of the Department of Military Settlements for 1840]. RGVIA [Russian State Military Historical Archive], f. 405, inv. 10, d. 251. 1191.
13. Otchet po 3-y i Bugskoy poselennym ulanskim diviziyam za minuvshiy 1821 god [Report on the $3^{\text {rd }}$ and Bug Settlement Ulan Divisions for the Past 1821]. RGVIA [Russian State Military Historical Archive], f. 405, inv. 1, d. 140, 1. 620-643.

14. Otchet po 3-y Ulanskoy poselennoy divizii za 1827 g. [Report on the $3^{\text {rd }}$ Ulan Settlement Division for 1827]. RGVIA [Russian State Military Historical Archive], f. 405, inv. 2, d. 771, 1. 140-158.

15. Otchety po Bugskoy i 3-y ulanskim i 3-y Kirasirskoy diviziyam za $1825 \mathrm{~g}$. [Reports on the Bug and $3^{\text {rd }}$ Ulan and $3^{\text {rd }}$ Cuirassier Divisions for 1825]. RGVIA [Russian State Military Historical Archive], f. 405, inv. 1, d. 407, 1. 790-961.

16. Otchet po voyennym poseleniyam za 1824 god [Report on Military Settlements for 1824]. Saint Petersburg, Tipografiya Shtaba voennykh poseleniy, $1825.153 \mathrm{p}$.

17. Petrov A.N. Ustroistvo i upravlenie voennymi poseleniyami v Rossii [Organization and Management of Military Settlements in Russia]. Graf Arakcheev $i$ voennye poseleniya. 1809-1831 [Count Arakcheev and Military Settlements. 1809-1831]. Saint Petersburg, Russkaya starina Publ., 1871, pp. 87-193.

18. Polozheniye i prikaz o uchebnom divizione $\mathrm{v}$ okruge voyennogo poseleniya kavaleriyskogo polka [Regulations and Order on the Training Division in the District of the Military Settlement of the Cavalry Regiment]. RGVIA [Russian State Military Historical Archive], f. 405, inv. 1, d. 407, 1. 204-206.

19. Polozheniye o polnom sostave poselennogo peshego polka i yego obyazannostyakh [Regulations on the Full Composition of the Settlement Infantry Regiment and Its Duties]. Saint Petersburg, Tipografiya Glavnogo shtaba E. I. V. po voennomu poseleniyu, $1826.39 \mathrm{p}$.

20. Polozheniye o voyennom poselenii regulyarnoy kavalerii [Regulations on the Military Settlement of the Regular Cavalry]. Saint Petersburg, Tipografiya Glavnogo shtaba E. I. V. po voennomu poseleniyu, $1827.77 \mathrm{p}$.

21. Polozheniye o sformirovanii iz voyennykh kantonistov kavaleriyskikh eskadronov $i$ artilleriyskikh batarey v okrugakh voyennogo poseleniya kavalerii [Regulation on the Formation of Cavalry Squadrons and Artillery Batteries from Military Cantonists in the Districts of a Military Cavalry Settlement]. PSZ RI-2 [The Complete Collection of Laws of the Russian Empire]. Saint Petersburg, Tipografiya II Otdeleniya S. E. I. V. kantselyarii, 1837, vol. XI, no. 9466, pp. 871-878.

22. Polozheniye ob uchebnom eskadrone $\mathrm{v}$ okruge poselennogo kavaleriyskogo polka [Regulations on the Training Squadron in the District of the Settlement Cavalry Regiment]. RGVIA [Russian State Military Historical Archive], f. 405, inv. 1, d. 382, 1. 245-320. 


\section{ВООРУЖЕННЫЕ СИЛЫ И ВОЕННЫЕ ДЕЙСТВИЯ}

23. Pravila o perekhode korennykh zhitelei v voennoe poselenie okruga voennogo poseleniya kavalerii [Rules on the Transfer of Indigenous Residents to a Military Settlement of the District of a Military Settlement of the Cavalry]. Graf Arakcheev $i$ voennye poseleniya. 1809-1831 [Count Arakcheev and Military Settlements. 1809-1831]. Saint Petersburg, Russkaya starina Publ., 1871, pp. 228-232.

24. Proekt Uchrezhdeniya o voennom poselenii pekhoty. Ch. 1-3 [Draft of the Institution on the Military Settlement of the Infantry. Pts. 1-3]. Saint Petersburg, Tipografiya K. Kraya, 1817.261 p.

25. Proekt Uchrezhdeniya o voennom poselenii regulyarnoi kavalerii. Ch. 2 [Draft of the Institution on the Military Settlement of the Regular Cavalry. Pt. 2]. Saint Petersburg, Tipografiya K. Kraya, 1817.96 p.

26. Rediger A. Unter-ofitserskii vopros v glavnykh evropeiskikh armiyakh [The Non-Commissioned Officer Question in the Main European Armies]. Saint Petersburg, Tipografiya Trenke i Fusno, 1880. 188 p.

27. Reskripty Aleksandra I Arakcheyevu i konfirmovannyye doklady i predlozheniya yego za 1821 g. [Rescripts of Alexander I to Arakcheev and Confirmed Reports and His Proposals for 1821]. RGVIA [Russian State Military Historical Archive], f. 405, inv. 1, d. 88.9091.

28. Rukovodstvo $k$ uchrezhdeniyu shkol dlya kantonistov srednego vozrasta po metode vzaimnogo obucheniya i $k$ upravleniyu onymi [A Guide to the Establishment of Schools for Middle-Aged Cantonese on the Method of Mutual Learning and Management There Of]. Saint Petersburg, [s. n.], 1819. 94 p.

29. Petrov A.N., ed. Russkaya voennaya sila. Istoriya razvitiya voennogo dela ot nachala Rusi do nashego vremeni [Russian Military Force. History of the Development of Military Affairs from the Beginning of Russia to Our Time]. Moscow, Tipo-Litografiya I.N. Kushnereva i Ko, 1892, vol. 2. 569 p.
30. Svedeniya $\mathrm{k}$ otchetu po voyennym poseleniyam za 1826 god [Information on the Report on Military Settlements for 1826]. RGVIA [Russian State Military Historical Archive], f. 405, inv. 2, d. 155. 3361.

31. Khronika rossiiskoi imperatorskoi armii, sostavlennaya po vysochaishemu poveleniyu. Ch. IV [Chronicle of the Russian Imperial Army Compiled by the Highest Order. Pt. IV]. Saint Petersburg, Voennaya tipografiya, $1852.611 \mathrm{p}$.

32. Khronika rossiiskoi imperatorskoi armii, sostavlennaya po vysochaishemu poveleniyu. Ch. 5 [Chronicle of the Russian Imperial Army, Compiled by the Highest Order. Pt. 5]. Saint Petersburg, Voennaya tipografiya, $1852.533 \mathrm{p}$.

33. Tsubenko V.L. Dokumenti iz istorii viyskovikh poselen' $v$ Ukraini [Documents on the History of Military Settlements in Ukraine]. Kharkiv, Vidavnitstvo SAGA, 2008. 374 p.

34. Shakirzyanov Eh.M. Podgotovka unterofitserskikh kadrov russkoi armii v pervoi polovine XIX v.: istoricheskoe issledovanie: avtoref. diss. kand. ist. nauk [Training of Non-Commissioned Officers in the Russian Army in the First Half of the XIX Century: A Historical Study. Cand. hist. sci. abs. diss.]. Moscow, 2011.24 p.

35. Shakirzyanov Eh.M. Stanovlenie sistemy podgotovki unter-ofitserskikh kadrov russkoi armii v pervoi polovine XIX v. [Formation of the System of Training Non-Commissioned Officers of the Russian Army in the First Half of the XIX Century]. Vestn. Voen. un-ta [Bulletin of the Military University], 2010, no. 1 (21), pp. 46-56.

36. Yachmenikhin V.K. Institut voennykh kantonistov v strukture russkoi armii [Institute of Military Cantonists in the Structure of the Russian Army]. Vestn. Mosk. un-ta. Seriya 8, Istoriya [Bulletin of Moscow University. Seriya 8. History], 2000, no. 1, pp. 55-68.

\section{Information About the Author}

Tatiana N. Kandaurova, Candidate of Sciences (History), Senior Researcher, Department of History and Theory of Culture, Russian State University for the Humanities, Miusskaya Sq., 6, 125993, GSP-3 Moscow, Russian Federation, tanikand@mail.ru, https://orcid.org/0000-0001-8167-1188

\section{Информация об авторе}

Татьяна Николаевна Кандаурова, кандидат исторических наук, старший научный сотрудник кафедры истории и теории культуры, Российский государственный гуманитарный университет, Миусская площадь, 6, 125993, ГСП-3 г. Москва, Российская Федерация, tanikand@mail.ru, https://orcid.org/0000-0001-8167-1188 